\title{
Histone H2AX
}

National Cancer Institute

\section{Source}

National Cancer Institute. Histone H2AX. NCI Thesaurus. Code C19432.

Histone H2AX (143 aa, $15 \mathrm{kDa}$ ) is encoded by the human H2AX gene. This protein plays a role in nucleosome formation and $V(D)$ J recombination. 